\title{
COMPUTATIONAL SCREENING AND MOLECULAR DOCKING OF LICHEN SECONDARY METABOLITES AGAINST SEVERE ACUTE RESPIRATORY SYNDROME-COV-2 MAIN PROTEASE AND SPIKE PROTEIN
}

\author{
SENTHIL PRABHU ${ }^{1 *}$, SATHISHKUMAR R ${ }^{2}$, KIRUTHIKA $B^{3}$ \\ ${ }^{1}$ Department of Microbiology, Dr. N.G.P. Arts and Science College, Coimbatore, Tamil Nadu, India; ${ }^{2}$ Department of Biotechnology, \\ Kongunadu Arts and Science College, Coimbatore, Tamil Nadu, India; ${ }^{3}$ Executive Board Member-Secretary, NJ Academy of Science Union, \\ New Jersey, USA. Email: sepisp@gmail.com \\ Received: 24 September 2021, Revised and Accepted: 05 November 2021
}

\section{ABSTRACT}

Objective: At present, the coronavirus disease (COVID)-19 pandemic is increasing global health concerns. This coronavirus outbreak is caused by severe acute respiratory syndrome coronavirus (SARS-CoV)-2. Since, no specific antiviral for treatment against COVID-19, so identification of new therapeutics is an urgent need. The objective of this study is to the analysis of lichen compounds against main protease and spike protein targets of SARS-CoV-2 using in silico approach.

Methods: A total of 108 lichen compounds were subjected to ADMET analysis and 14 compounds were selected based on the ADMET properties and Lipinski's rule of five. Molecular docking was performed for screening of selected individual lichen metabolites against the main protease and spike proteins of SARS-CoV-2 by Schrodinger Glide module software.

Results: Among the lead compounds, fallacinol showed the highestbinding energy value of-11.83 kcal/mol against spike protein,4-0-Demethylbarbatic acid exhibited the highest dock score of $-11.67 \mathrm{kcal} / \mathrm{mol}$ against main protease.

Conclusion: This study finding suggests that lichen substances may be potential inhibitors of SARS-CoV-2.

Keywords: Coronavirus disease-19, Severe acute respiratory syndrome coronavirus-2, Docking, Lichen Compounds, Main protease, Spike protein.

(C) 2021 The Authors. Published by Innovare Academic Sciences Pvt Ltd. This is an open access article under the CC BY license (http://creativecommons.org/ licenses/by/4.0/) DOI: http://dx.doi.org/10.22159/ajpcr.2021v14i12.43227. Journal homepage: https://innovareacademics.in/journals/index.php/ajpcr

\section{INTRODUCTION}

Coronavirus disease (COVID-19) was emerged from Wuhan city, China, in December 2019 as an epidemic, this disease mainly targets the human respiratory system $[1,2]$. According to the World Health Organization, 202,608,306 confirmed cases and 4,293,591 deaths were reported globally as of August 9, 2021 [3]. This virus mainly spread through droplets produced from sneezing, coughing, talking, and close contact with the infected person [4,5]. COVID-19 patients are treated using symptomatic therapy due to the unavailability of approved specific drugs [6]. Hence, there is an urgent need to discover drugs for the clinical management of COVID-19.

Severe acute respiratory syndrome coronavirus (SARS-CoV)-2 contains positive-sense single-stranded RNA (+ssRNA) as genetic material and this virus produces nearly $800 \mathrm{KD}$ polypeptides. These polypeptides encode main protease $\left(M^{\text {pro }}\right)$ and RNA-dependent RNA polymerase (RdRp), spike protein (S protein) other structural proteins $[7,8]$. Main protease is an essential enzyme for viral replication, involved in cleaving polypeptides and mediating replication and transcription. Hence, main protease $\left(M^{\text {pro }}\right)$ is one of the key targets to stop viral replication. Spike protein (S protein) is a surface protein that helps for virus attachment with angiotensin-converting enzyme 2 (ACE 2) receptors. Thus, spike $(S)$ protein is considered as one of the main target for COVID-19 therapeutics [9].

Lichens are a symbiotic association of fungi and algae; occur in a variety of habitats and natural environmental conditions. Lichen metabolites were reported to exhibit intense analgesic, antipyretic [10], anti-inflammatory [11], antimicrobial [12], antiviral [13], and cytotoxic activities [14]. The current scenario of molecular docking and computational studies opens new possibilities of drug screening and may assist in the development of COVID-19 treatment [15].
The aim of the present study was made to screening the lichen substances to identifying the potential drug to inhibit SARS-CoV-2 main protease and spike protein by molecular docking method.

\section{METHODS}

\section{Accession of target protein}

The COVID-19 main protease ( $\mathrm{M}^{\mathrm{pro}}$ ) and spike proteins (S protein) were selected as target proteins. The X-ray crystal structure of the above proteins was retrieved from the Protein Data Bank database (PDB ID: 6lu7 and 6M0J) for this virtual screening study [https://www.rcsb.org/ pdb/home/home.do].

\section{Ligand selection}

A total of 108 lichen metabolites were selected and retrieved that the compounds were from the PubChem database as SDF format and it was subsequently converted into PDB format using Open Babel free software. The retrieved structure energy was minimized and hydrogen atoms were added and charges were assigned using Gasteiger.

\section{ADME prediction}

The ADME (Adsorption, Distribution, Metabolism, and Excretion) properties were analyzed for the compounds to test its drug-likeness using QikProp, a Schrodinger module. The ADME properties are important to find the pharmacodynamics of selected molecules that could be used as drug.

\section{Molecular docking}

Finally, the 12 lichen compounds which are exhibiting drug-likeness were taken to account for docking studies using the Glide module. The interactions of selected proteins and lichen compounds were observed using PyMOL software [16,17]. 


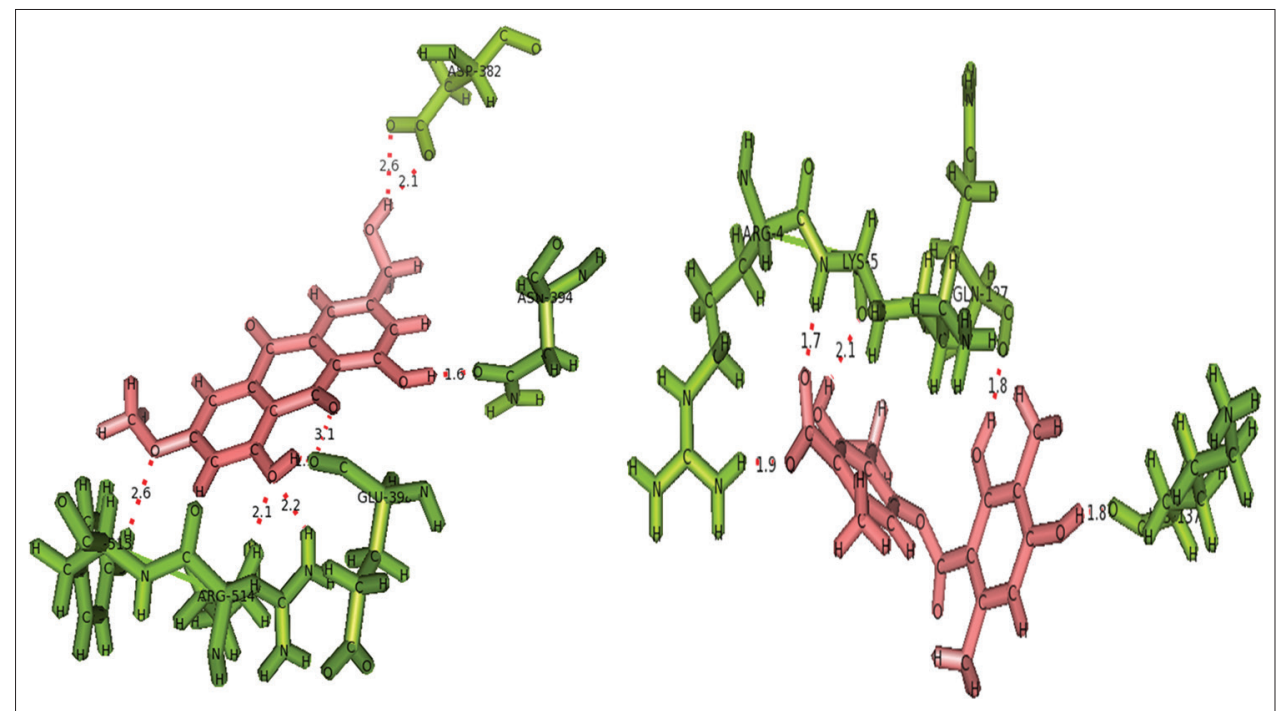

Fig. 1: (a) Interaction of fallacinol with spike protein (6M0J). (b) Interaction of 4-0-Demethylbarbatic acid with main protease (6lu7)

Table 1: Interactions of selected lichen compounds with SARS-CoV-2 target proteins

\begin{tabular}{|c|c|c|c|c|}
\hline Ligand (PubChem ID) & G-score (kcal/mol) & Bond length (Å) & No. of hydrogen bonds & Interacting residues \\
\hline \multicolumn{5}{|l|}{ Main protease (PDB ID: 6lu7) } \\
\hline \multirow[t]{5}{*}{ 4-0-Demethylbarbatic acid (10450302) } & -11.67 & 1.8 & 5 & LYS-137 (O-H) \\
\hline & & 2.1 & & LYS-5 (O-H) \\
\hline & & 1.7 & & LYS-5 (H-O) \\
\hline & & 1.8 & & GLN-127 (O-H) \\
\hline & & 1.9 & & ARG-4 (H-O) \\
\hline \multirow{3}{*}{ Emodin (3220) } & & 2.5 & & LYS- $137(\mathrm{O}-\mathrm{H})$ \\
\hline & & 3.1 & & GLN-127 (O-O) \\
\hline & & 2.1 & & GLN-127 (H-O) \\
\hline \multirow[t]{3}{*}{ Diploschistic acid (12309260) } & -11.36 & 1.9 & 3 & GLN-110 (O-H) \\
\hline & & 2.3 & & GLN-110 (O-H) \\
\hline & & 1.7 & & ASP-153 (O-H) \\
\hline \multirow[t]{3}{*}{ Evernic acid (10829) } & -10.73 & 1.9 & 4 & GLN-110 (O-H) \\
\hline & & 1.9 & & ASP153 (O-H) \\
\hline & & 2.3 & & LYS-102 (H-O) \\
\hline \multirow[t]{4}{*}{ Fallacinol (3083633) } & -10.25 & 1.9 & 4 & LYS-137 (O-H) \\
\hline & & 3.1 & & LYS-5 (O-0) \\
\hline & & 2.1 & & GLN-127 (H-O) \\
\hline & & 2.5 & & ARG-4 (H-O) \\
\hline \multirow[t]{2}{*}{ Lecanoric acid (99613) } & -10.66 & 1.8 & 2 & ASP-153 (O-H) \\
\hline & & 2.1 & & GLN-110 (O-H) \\
\hline \multirow[t]{3}{*}{ Olivetolic acid (2826719) } & -9.27 & 1.8 & 3 & LYS-5 (H-O) \\
\hline & & 1.9 & & GLU-288 (O-H) \\
\hline & & 1.9 & & ASP-289 (O-H) \\
\hline Strepsilin (12443050) & -8.13 & 2.0 & 1 & LYS-137 (O-H) \\
\hline \multirow[t]{2}{*}{ Norlichexanthone (5281657) } & -8.3 & 1.9 & 2 & LYS-137 (O-H) \\
\hline & & 2.1 & & LYS-5 (H-O) \\
\hline \multirow[t]{2}{*}{ Haematommone (11066989 } & -7.24 & 2.7 & 2 & LYS-5 (H-O) \\
\hline & & 2.1 & & GLU-290 (O-H) \\
\hline \multirow[t]{2}{*}{ Pannaric acid (12313948) } & -7.11 & 1.6 & 4 & LYS-5 (H-O) \\
\hline & & 1.6 & & $\mathrm{ARG}-4(\mathrm{H}-\mathrm{O})$ \\
\hline \multirow[t]{3}{*}{ Citreorosein (361512) } & -6.89 & 2.2 & 3 & LYS-137 (O-H) \\
\hline & & 1.7 & & ASP-289 (O-H) \\
\hline & & 1.8 & & GLU-288 (O-H) \\
\hline \multirow{2}{*}{ Protocetraric acid (5489486) } & -6.65 & 1.6 & 2 & ASP-289 (O-H) \\
\hline & & 1.8 & & LYS-5 (H-O) \\
\hline \multirow{3}{*}{ Convirensic acid (101657446) } & -6.02 & 2.5 & 3 & LYS-137 (O-H) \\
\hline & & 2.0 & & ARG-4 (H-O) \\
\hline & & 1.9 & & GLU-288 (O-H) \\
\hline
\end{tabular}


Table 1: (Continued)

\begin{tabular}{|c|c|c|c|c|}
\hline Ligand (PubChem ID) & G-score (kcal/mol) & Bond length (Å) & No. of hydrogen bonds & Interacting residues \\
\hline \multicolumn{5}{|l|}{ Spike protein (PDB ID: 6M0J) } \\
\hline \multirow[t]{8}{*}{ Fallacinol (3083633) } & -11.83 & 1.6 & 8 & ASN-394 (O-H) \\
\hline & & 2.6 & & ASP-382 (O-H) \\
\hline & & 2.1 & & ASP-382 (O-H) \\
\hline & & 2.6 & & TYR-515 (H-O) \\
\hline & & 2.2 & & ARG-514 (H-O) \\
\hline & & 2.1 & & ARG-514 (H-O) \\
\hline & & 1.9 & & GLU-398 (O-H) \\
\hline & & 3.1 & & GLU-398 (0-0) \\
\hline \multirow[t]{7}{*}{ Pannaric acid (12313948) } & -11.78 & 3.1 & 7 & HIS- $345(\mathrm{~N}-\mathrm{H})$ \\
\hline & & 1.9 & & TYR -127 (H-O) \\
\hline & & 2.8 & & TYR -127 (H-O) \\
\hline & & 2.0 & & TYR -515 (H-O) \\
\hline & & 2.1 & & ARG-273 (H-O) \\
\hline & & 2.1 & & ARG-273 (H-O) \\
\hline & & 1.7 & & ARG-273 (H-O) \\
\hline \multirow[t]{7}{*}{ Diploschistic acid (12309260) } & -11.74 & 2.6 & 7 & HIS -505 (H-O) \\
\hline & & 1.8 & & ARG-273 (H-O) \\
\hline & & 1.7 & & ARG-273 (H-O) \\
\hline & & 1.9 & & GLU-402 (O-H) \\
\hline & & 2.2 & & HIS -378 (H-O) \\
\hline & & 2.0 & & GLU-375 (O-H) \\
\hline & & 1.8 & & ALA-348 (H-O) \\
\hline \multirow[t]{5}{*}{ Lecanoric acid (99613) } & -11.58 & 2.2 & 5 & GLU-375 (O-H) \\
\hline & & 2.6 & & HIS -505 (H-O) \\
\hline & & 1.9 & & ARG-273 (H-O) \\
\hline & & 2.1 & & ARG-273 (H-O) \\
\hline & & 2.1 & & ALA-348 (O-H) \\
\hline \multirow[t]{5}{*}{ Haematommone (11066989) } & -11.37 & 1.8 & 5 & GLU-398 (O-H) \\
\hline & & 1.7 & & ARG-514 (H-O) \\
\hline & & 2.6 & & ARG-514 (H-O) \\
\hline & & 2.1 & & ALA-348 (O-H) \\
\hline & & 2.1 & & GLU-375 (O-H) \\
\hline \multirow[t]{5}{*}{ Convirensic acid (101657446) } & -10.03 & 2.0 & 5 & GLU -406 (O-H) \\
\hline & & 2.0 & & GLU -402 (O-H) \\
\hline & & 1.7 & & GLU -402 (O-H) \\
\hline & & 2.0 & & ARG-518 (H-O) \\
\hline & & 1.7 & & ARG-518 (H-O) \\
\hline \multirow[t]{5}{*}{ Evernic acid (10829) } & -10.65 & 2.1 & 5 & ARG-514 (H-O) \\
\hline & & 2.3 & & ASN-394 (O-H) \\
\hline & & 1.7 & & LYS -562 (H-O) \\
\hline & & 2.8 & & LYS -562 (H-O) \\
\hline & & 2.7 & & GLY-395 (O-H) \\
\hline \multirow[t]{6}{*}{ Strepsilin (12443050) } & -10.57 & 1.7 & 6 & GLU -398 (O-H) \\
\hline & & 2.8 & & ARG-514 (H-O) \\
\hline & & 2.1 & & ARG-514 (H-O) \\
\hline & & 2.2 & & ARG-514 (H-O) \\
\hline & & 2.5 & & TYR-515 (H-O) \\
\hline & & 2.0 & & ALA-348 (O-H) \\
\hline \multirow[t]{4}{*}{ Citreorosein (361512) } & -10.49 & 2.0 & 4 & ALA-348 (O-H) \\
\hline & & 1.8 & & GLU -398 (O-H) \\
\hline & & 2.0 & & ARG-514 (H-O) \\
\hline & & 2.5 & & TYR-515 (H-O) \\
\hline \multirow[t]{5}{*}{ Emodin (3220) } & & 2.2 & 5 & TYR-515 (H-O) \\
\hline & & 1.8 & & ARG-514 (H-O) \\
\hline & & 3.0 & & GLU -398 (0-0) \\
\hline & & 2.0 & & GLU -398 (O-H) \\
\hline & & 2.4 & & ASN-394 (O-H) \\
\hline \multirow[t]{6}{*}{ 4-0-Demethylbarbatic acid (10450302) } & -9.98 & 1.8 & 6 & GLU -395 (O-H) \\
\hline & & 2.1 & & GLU -402 (O-H) \\
\hline & & 2.1 & & ARG-514 (H-O) \\
\hline & & 2.1 & & ARG-514 (H-O) \\
\hline & & 1.9 & & ARG-514 (H-O) \\
\hline & & 1.8 & & GLU -398 (O-H) \\
\hline
\end{tabular}


Table 1: (Continued)

\begin{tabular}{|c|c|c|c|c|}
\hline Ligand (PubChem ID) & G-score (kcal/mol) & Bond length $(\AA ̊)$ & No. of hydrogen bonds & Interacting residues \\
\hline \multirow[t]{6}{*}{ Norlichexanthone (5281657 } & -9.65 & 2.6 & 6 & ASP-382 (O-H) \\
\hline & & 1.9 & & ASP-382 (O-H) \\
\hline & & 2.0 & & GLU-402 (O-H) \\
\hline & & 3.2 & & GLU-402 (0-0) \\
\hline & & 1.8 & & GLU -398 (O-H) \\
\hline & & 1.7 & & ARG-514 (H-0) \\
\hline \multirow{4}{*}{ Olivetolic acid (2826719) } & -8.5 & 1.7 & 4 & ARG-514 (H-O) \\
\hline & & 1.7 & & ARG-514 (H-O) \\
\hline & & 2.2 & & TYR-515 (H-O) \\
\hline & & 2.0 & & GLU -398 (O-H) \\
\hline \multirow[t]{4}{*}{ Protocetraric acid (5489486) } & -7.6 & 2.1 & 4 & GLN-442 (H-O) \\
\hline & & 2.2 & & ARG-518 (H-0) \\
\hline & & 1.9 & & GLU-406 (O-H) \\
\hline & & 2.7 & & SER-409 (H-0) \\
\hline
\end{tabular}

SARS-CoV: Severe acute respiratory syndrome coronavirus<smiles>COc1cc(O)c2c(c1)C(=O)c1cc(CO)cc(O)c1C2=O</smiles>

Fig. 2: (a) Chemical structure if fallacinol (b) chemical structure 4-0-Demethylbarbatic acid

\section{RESULTS}

Molecular docking studies of lichen secondary metabolites (14 compounds) were carried out with SARS-CoV-2 proteins. The interactions of lichen metabolites with main protease and spike protein of SARS-CoV-2 tabulated with G-Score, number of hydrogen bonds, bond length, and the interacting residues (Table 1). The amino acid residues of the proteins (6lu7 and 6M0J) were determined by LIGSITE tool. The residues are Lys-5, Lys-137, Gln-110, Gln-127, Glu-288, Glu-290, Arg-4, Asp-153, Lys-102, Asp-289 and Asn-394, Asp-382, Tyr-127,Tyr-515, Arg-273, Arg-514, Arg-518, Glu-375 Glu-398, Glu402, Glu-406, His-345, His-378, His-505, Ala-348, Gln-442, and Ser-409. Among the lichen compounds, fallacinol and 4-0-Demethylbarbatic acid exhibited the least $\mathrm{G}$ score $(-11.83 \mathrm{kcal} / \mathrm{mol}$ and $-11.67 \mathrm{kcal} / \mathrm{mol})$ against spike protein and main protease respectively with 8 and 5 hydrogen bonds. The residues Asn-394, Asp-382, Tyr-515, Arg-514, and Glu-398 of spike protein and Lys-137, Lys-5, Gln-127, and Arg-4 of the main protease are predicted as active sites and had interactions with above said ligands, respectively. The bond lengths were observed as $2.6,2.1,2.6,2.2,2.1,1.9$, $3.1 \AA$ and $1.8,2.1,1.7,1.8,1.9 \AA$ with respect to the above residues of both proteins. The interaction of fallacinol and 4-0-Demethylbarbatic acid with SARS-CoV-2 proteins shown in Fig. 1 and 2D structures of fallacinol and 4-0-Demethylbarbatic acid are shown in Fig. 2.

The compounds emodin and diploschistic acid were also showed significant binding affinity $(-11.56 \mathrm{kcal} / \mathrm{mol}$ and $-11.36 \mathrm{kcal} / \mathrm{mol})$ against the main protease with 4 and 3 hydrogen bonds, respectively.
Pannaric acid, diploschistic acid, lecanoric acid, and haematommone have shown good binding affinity of $-11.78 \mathrm{kcal} / \mathrm{mol},-11.74 \mathrm{kcal} / \mathrm{mol}$, $-11.58 \mathrm{kcal} / \mathrm{mol}$, and $-11.37 \mathrm{kcal} / \mathrm{mol}$, respectively, with spike protein, each formed 7, 7, 5, and 5 hydrogen bonds. The above compounds have shown ADME properties and drug-likeness was also noteworthy.

Note: Split pea green color represents the amino acid residues of the protein and deep salmon red color indicates the ligands.

\section{DISCUSSION}

The in silico method such as docking is an effective strategy and widely used method for understanding the molecular aspects of proteins and protein-ligand interactions in the drug discovery process [18]. Identification of effective drugs for treating COVID-19 patients is an urgent need of global pandemic COVID-19. The various discoveries made through computational studies possess significance in regard the discovery of a potential drug, as the success of the derived molecules is obvious. The present study indicates the efficient binding of lichen compounds such as fallacinol and 4-0-Demethylbarbatic acid with the active amino acid residues of the main protease and spike protein of SARS-CoV-2 with the least G-Score.

\section{CONCLUSION}

This study finding suggested that the use of naturally occurring lichen substances could serve as efficient therapeutics for the treatment of COVID-19. Through this structural bioinformatics approach, some of the lichen compounds are potential against the protein targets (main protease and spike protein) of SARS-CoV-2.

\section{ACKNOWLEDGMENT}

The author's thanks to the Department of Biotechnology, Kongunadu Arts and Science College, Coimbatore, India, and Department of Microbiology, Dr. N.G.P. Arts and Science College, Coimbatore, for given the facilities to carry out this study. We also extend our thanks to DBT FIST and DBT Star Scheme, Government of India, for provided the support to this study.

\section{AUTHORS' CONTRIBUTIONS}

Each author has given considerable and equal contributions to this research.

\section{CONFLICTS OF INTEREST}

The authors declare that there are no conflicts of interest.

\section{AUTHORS FUNDING}

Not applicable. 


\section{REFERENCES}

1. Moore N. Chloroquine for COVID-19 infection. Drug Saf 2020;43:393-4.

2. Ul Qamar MT, Alqahtani SM, Alamri MA, Chen LL. Structural basis of SARS-CoV-2 3CLpro and anti-COVID-19 drug discovery from medicinal plants. J Pharm Anal 2020;10:313-9.

3. World Health Organization, Report; 2021. Available from: https:// covid19.who.int

4. Cascella M, Rajnik M, Cuomo A, Dulebohn SC, Di Napoli R. Evaluation and Treatment Coronavirus (COVID-19). Treasure Island, FL, USA: Stat Pearls Publishing LLC; 2020.

5. Zhou F, Yu T, Du R, Fan G, Liu Y, Liu Z, et al. Clinical course and risk factors for mortality of adult in patients with COVID-19 in Wuhan, China: A retrospective cohort study. Lancet 2020;395:1054-62.

6. Gabutti G, d'Anchera E, Sandri F, Savio M, Stefanati A. Coronavirus: Update related to the current outbreak of COVID-19. Infect Dis Ther 2020;4:1-3.

7. Elfiky AA. Anti-HCV, nucleotide inhibitors, repurposing against COVID-19. Life Sci 2020;248:117-477.

8. Chen Y, Liu Q, Guo D. Emerging coronaviruses: Genome structure, replication, and pathogenesis. J Med Virol 2020;92:418-23.

9. Pandey P, Rane JS, Chatterjee A, Kumar A, Khan R, Prakash A, et al. Targeting SARS-CoV-2 spike protein of COVID-19 with naturally occurring phytochemicals: An in silico study for drug development. J Biomol Struct Dyn 2021;39:6306-16.

10. Okuyama E, Umeyama K, Yamazaki M, Kinoshita Y, Yamamoto Y. Usnic acid and diffractic acid as analgesic and antipyretic components of Usnea diffracta. Planta Med 1995;61:113-5.

11. Vijayakumar CS, Viswanathan S, Reddy MK, Parvathavarthini S, Kundu AB, Sukumar E. Anti-inflammatory activity of (+) -usnic acid. Fitoterapia 2000;71:564-6.

12. Rashid MA, Bhuiyan MS, Hossain MA, Quader MA, Nutan MT, Karim MR. (+)- Usnic acid, an antimicrobial agent from Permelia kamtschandalis. Pak J Microbiol 2001;1:26-8.

13. Esimone CO, Grunwald T, Nworu CS, Kuate S, Proksch P, Uberla K. Broad spectrum antiviral fractions from the lichen Ramalina farinacea (L.) Arch Chemother 2009;55:119-26.

14. Eugenia C, Pereira SC, Nascimento RC, Lima NH, Silva AF, Oliveira EB, et al. Analysis of Usnea fasciata crude extracts with antineoplastic activity. Tokai J Exp Clin Med 1994;19:47-52.

15. Dong S, Sun J, Mao Z, Wang L, Lu YL, Li J. A guideline for homology modeling of the proteins from newly discovered betacoronavirus, 2019 novel coronavirus (2019-nCoV). J Med Virol 2020;2:1542-8.

16. Sreeja S, Smith AA, Madan S, Sunilkumar D, Vani V. Computational molecular modelling of 2-aminobenzimidazole derivatives: Strong successor of hypoglycaemic agent. Int J Pharm Pharm Sci 2021;13:16-21.

17. Badavath VN, Sinha BN, Jayaprakash V. Design, in-silico docking and predictive ADME properties of novel pyrazoline derivatives with selective human mao inhibitory activity. Int J Pharm Pharm Sci 2021;7:277-82.

18. Murgueitio MS, Bermudez M, Mortier J, Wolber G. In silico virtual screening approaches for anti-viral drug discovery. Drug Discov Today Techno 2012;19:219-25 